\title{
ПРОБЛЕМИ ТА ПЕРСПЕКТИВИ ВИКЛАДАННЯ ПАЛІАТИВНОЇ ДОПОМОГИ НА ЕТАПІ ПІДГОТОВКИ МАГІСТРІВ МЕДСЕСТРИНСТВА
}

H. I. Рега

ДВНЗ “Тернопільський державний медичний університет імені І. Я. Горбачевського МОЗ Украӥни”

\section{THE PROBLEMS AND PERSPECTIVES OF TEACHING OF THE PALLIATIVE CARE AT THE STAGE OF TRAINING OF MASTERS OF NURSING}

\author{
N. I. Reha \\ SHEI "Ternopil State Medical University by I. Ya. Horbachevsky of MPH of Ukraine"
}

\begin{abstract}
Предмет "Паліативна медицина" охоплюс засвосння комплексу медичних, соціальних, психологічних та духовних заходів, спрямованих на поліпшення якості життя паціснтів, які мають невиліковну хворобу та обмежений прогноз життя, а також членів їхніх сімей. Головні завдання паліативної допомоги - позбавлення від болю, усунення або зменшення розладів життедіяльності та інших тяжких проявів хвороби, а також догляд, психологічна, соціальна та духовна допомога пацієнту та його рідним.
\end{abstract}

The subject "Palliative Medicine" includes the mastering of complex medical, social, psychological and spiritual activities aimed at improving the quality of life of patients with terminal illness and the limited outlook of life and their family members. The main objectives of palliative care are pain disappearance, removal or reduction of life disorders and other serious manifestations of the disease, care, psychological, social and spiritual care for patients and their families.

Вступ. Паліативна допомога - це підхід, який дозволяє покращити якість життя пацієнтів із невиліковними захворюваннями та допомогти членам їхніх родин шляхом запобігання та полегшення страждань невиліковно хворої людини (визначення ВООЗ, 2002 р.). Головною метою паліативної допомоги $є$ підтримка якості життя у його фінальній стадії, максимальне полегшення фізичних і моральних страждань пацієнта та його близьких, а також збереження людської гідності пацієнта. Паліативну допомогу можна надавати разом із допомогою, спрямованою на одужання, але ії мета не виліковування, а піклування.

Основні засади надання паліативної допомоги:

- полегшення болю та інших симптомів невиліковної хвороби;

- надання підтримки, яка допомагає вести максимально творче життя;

- покращення якості життя.

Відповідно до сучасних міжнародних підходів та концепцій, паліативна медицина повинна бути невід'ємною, інтегрованою складовою медичного обслуговування та соціальної опіки. Декларація ВОО3 (1990) та Барселонська декларація (1996) закликають усі держави світу включити паліативну допомо(c) H. I. Рега гу в структуру національних систем охорони здоров'я [1]. За характеристикою медико-демографічної ситуації, Україна належить до демографічно старих країн світу [2]. Частка населення віком 60 років і старших становить понад 11 мільйонів осіб (або 23,9 \%), кількість людей, старших за 75 років, дорівнює близько 3,5 млн осіб, і їх кількість буде невпинно зростати. Постаріння населення в Україні, як і в інших країнах Європи, призводить до збільшення кількості людей, які помирають у старечому віці від хронічних соматичних хвороб, що супроводжуються важкими фізичними та психічними розладами, і потребують паліативної та хоспісної допомоги $[3,4]$. Щорічно в Україні реєструється близько 160000 хворих на онкологічні захворювання, а понад 90 тисяч пацієнтів помирають від цієї недуги, у більшості з яких розвивається надзвичайно сильний больовий синдром. Ефективного контролю болю в таких пацієнтів можна досягти лише при застосуванні опіоїдних анальгетиків. Уже до 2020 року прогнозується збільшення захворюваності на онкологічні недуги до 200 тисяч. Окрім того, члени сімей паліативних пацієнтів також потребують професійної допомоги. Невиліковно хвора людина спричиняє зниження якості життя всієї 
родини, стає причиною тяжких психологічних, соціальних та економічних розладів функціонування, зубожіння та руйнування сім’ї. Якщо до кількості паліативних хворих додати ще по 1-2 родичів, які доглядають за ними, то виходить, що близько 1,5 млн осіб щороку потребують паліативної та хоспісної допомоги, адже вони страждають від фізичного та морального болю, бо безсилі допомогти рідній людині. У всьому світі спостерігається тенденція до збільшення кількості хворих з поширеними формами злоякісних новоутворень. За даними Всесвітньої організації охорони здоров' я, щоденно у світі від болю страждає 3,5 мільйона онкохворих [5, 6]. Кожного року майже півмільйона осіб в Україні можуть потребувати послуг паліативної допомоги для полегшення симптомів хвороб, що загрожують життю [7]. До них належать хвороби системи кровообігу, у тому числі хронічні хвороби серця (майже 489000 смертей на рік), рак (100 000), респіраторні хвороби (28 000), туберкульоз (10 000), неврологічні розлади, у тому числі хвороба Альцгеймера (6 500) та ВІЛ/СНІД (близько 2 500) [8, 9]. Саме тому паліативна допомога є важливою складовою системи охорони здоров'я та соціального захисту громадян України, вона забезпечує реалізацію прав людини на гідне завершення життя та максимальне зменшення болю і страждань. Паліативна допомога-це комплекс медичних, соціальних, психологічних та духовних заходів, спрямованих на поліпшення якості життя пацієнтів, які мають невиліковну хворобу та обмежений прогноз життя, а також членів їхніх сімей. Головні завдання паліативної допомоги - позбавлення від болю, усунення або зменшення розладів життєдіяльності та інших тяжких проявів хвороби, а також догляд, психологічна, соціальна та духовна допомога пацієнту та його рідним як в умовах спеціалізованого медично-соціального закладу - хоспісу, так і вдома [10, 13, 14].

Всесвітня організація охорони здоров'я рекомендує всім країнам забезпечити належне навчання медичних працівників основ надання паліативної допомоги та знеболення. Проте в Україні офіційні програми навчання до- та післядипломної медичної освіти як для лікарів, так і для медичних сестер не забезпечують надання спеціалізованих знань та навичок щодо паліативної допомоги та знеболення. Протоколи ВООЗ щодо лікування больового синдрому, спричиненого раком, майже не викладаються у медичних ВНЗ та навчальних закладах для середнього медичного персоналу. Багато медичних працівників, зокрема медичних сестер, не розуміють головних принципів лікування больового синдрому та паліативної допомоги.

Особливим аспектом даної проблеми є професійна підготовка лікарів та медичних сестер, які працюють в паліативній і хоспісній медицині. Для цього були розроблені та затверджені навчальні програми для різних категорій лікарів та організаторів охорони здоров'я, а також для медичних сестер-магістрів 3 надання паліативної допомоги у лікувально-профілактичних закладах України. До того ж була створена перша в Україні кафедра паліативної та хоспісної медицини в НМАПО ім. П. Л. Шупика. Зараз в Україні існує велика потреба у розвитку паліативної допомоги, проте, на жаль, система охорони громадського здоров'я України та соціального захисту населення тільки починає звертати увагу на цю проблему. Українські фахівці, що фактично надають елементи паліативної допомоги, - лікарі, медичні сестри, соціальні працівники, геріатри, працівники громадських благодійних організацій тощо не володіють повним комплексом необхідних знань та навичок з паліативної допомоги. Це є причиною недоступності паліативної допомоги для пацієнтів (особливо це стосується знеболення), у багатьох випадках - ненадання або надання в обмеженому обсязі, тобто низької якості надання паліативної допомоги. Тому актуальною проблемою на сьогодні $є$ запровадження навчальних програм підготовки фахівців з паліативної допомоги, що є запорукою зміни ситуації у сфері охорони здоровя щодо надання паліативної допомоги, оскільки велика частина медперсоналу не може надати кваліфікованої допомоги таким пацієнтам у зв'язку з тим, що питання паліативного лікування і догляду за термінальними хворими не включені в курс навчання ні лікарів, ні медсестер [11]. Викладання питань організації паліативної й хоспісної допомоги необхідне для вивчення не лише наявних проблем, а й етичних принципів паліативної допомоги, історії хоспісного руху, питань якості життя інкурабельних хворих і їхніх родичів. Знання, набуті на практичних і семінарських заняттях та висвітлені в лекційному матеріалі, дозволяють забезпечити наступність між лікувальнопрофілактичними закладами охорони здоров' я і закладами соціального захисту населення, брати участь у проведенні медично-соціальної реабілітації, поліпшити якість надання медичної допомоги інкурабельним хворим в амбулаторно-поліклінічних умовах, а також приділити увагу різноманітним аспектам психологічної підтримки родичів хворих із тяжкими прогресуючими захворюваннями $[10,12,15]$.

Основна частина. На сьогодні в ТДМУ ім. І. Я. Горбачевського курс паліативної медицини 
викладається при підготовці медичних сестермагістрів, які навчаються на дистанційній формі навчання. Відомо, що магістр медсестринства відіграє значну роль в організації лікувального процесу, а саме, з одного боку, є організатором роботи медичних сестер у лікувальному закладі, а з іншого - покликаний здійснювати викладацьку діяльність, готуючи медичних сестер-молодших спеціалістів та медичних сестер-бакалаврів. Тому досконале знання магістрами медсестринства основ паліативної допомоги буде значно сприяти ії ефективному впровадженню в комплексну медичну допомогу населенню.

На сьогодні для підготовки медичної сестри-магістра створена базова робоча навчальна програма 3 паліативної медицини. Метою навчальної програми 3 паліативної медицини є: набуття медсестрами-магістрами практичних навичок з догляду за інкурабельними пацієнтами, засвоєння принципів паліативної медицини та ознайомлення з психологічними, соціальними і моральними аспектами спілкування 3 хворими і їх родичами [16]. Завданнями навчальної програми з паліативної медицини є:

- розуміння концепції і принципів паліативної медичної допомоги;

- вміння правильно оцінювати клінічні прояви захворювання при його прогресуванні та обгрунтувати перехід від радикального до паліативного лікування;

- вміння застосовувати основні методи інструментальної та медикаментозної корекції болю та інших ускладнень захворювання;

-знання психологічних, етичних, соціальних та релігійних аспектів паліативної медицини;

- вміння оцінювати якість життя хворих і визначати найбільш суттєві фактори, котрі впливають на неї.

Програма розрахована на 216 год, 3 них 12 год лекції, 60 год - практичні заняття, 144 год - самостійна позааудиторна робота. Під час вивчення дисципліни студенти оволодівають практичними навичками 3 догляду за інкурабельними хворими. Особлива увага приділяється психологічним аспектам паліативної медичної допомоги. Знання студентів 3 паліативної медицини оцінюються за 12-бальною шкалою. Студенти, які мають академічну заборгованість або не засвоїли практичні навички, до іспиту не допускаються.

Теоретична частина програми висвітлює такі теми:

1. Поняття про паліативну медичну допомогу.

2. Загальні принципи паліативної терапії хворих iз термінальними формами захворювань.

3. Якість життя.

4. Психологічні проблеми термінальних станів.
5. Етичні проблеми термінальних станів.

6. Вибір методу лікування. Профілактика і лікування різних симптомів.

7. Боротьба з болем.

8. Профілактика і лікування розладів травної системи.

9. Профілактика і лікування розладів дихальної системи.

10. Профілактика і лікування розладів сечовидільної системи.

11. Профілактика і лікування уражень шкіри і м'яких тканин.

12. Причини та механізми розвитку ендотоксикозу в онкологічних хворих.

13. Кахексія.

14. Кровотечі.

15. Останні години життя пацієнта.

У процесі практичної роботи проводиться обстеження пацієнтів із поширеним пухлинним процесом разом $з$ лікарем. Використовуючи деонтологічні принципи і правила комунікативної медицини, збирається анамнез і проводиться фізикальне обстеження хворого. Оцінюються дані інструментальних і лабораторних методів. За даними клінічного, інструментальних і лабораторних обстежень необхідно виділити ведучий синдром, який визначає тяжкість стану пацієнта. Разом $з$ лікарем-куратором з наявного арсеналу вибирається оптимальний метод або комбінація методів лікування пацієнта. Оволодівається практичними навиками: догляд за стомами, профілактика пролежнів, правила лікувального масажу та ін.

За одне заняття кожен студент отримує 1 кінцеву оцінку, яка є середнім арифметичним оцінок за кожний вид діяльності (практична робота, семінарське обговорення практичної роботи і тестовий контроль). Усі оцінки виставляються за 12-бальною шкалою.

На сьогодні в ТДМУ ім. І. Я. Горбачевського паліативну медицину вивчають 54 медичних сестермагістрів, які навчаються на дистанційній формі навчання, 3 них 41 вітчизняних, a 13 - іноземних. Однак пропонується включення викладання питань паліативної та хоспісної допомоги для інших студентів навчально-наукового інституту медсестринства та інших факультетів університету.

Висновки. Стан медичної освіти 3 питань паліативної допомоги вимагає активного впровадження таких заходів:

- вдосконалювати систему до- і післядипломної підготовки фахівців з паліативної та хоспісної допомоги, розробити навчальні програми підготовки не тільки для підготовки магістрів медсестринства, а й 
студентів інших медичних спеціальностей та підвищення кваліфікації фахівців для первинної паліативної допомоги та для закладів спеціалізованої паліативної і хоспісної медицини;

- розробити підручники та навчальні посібники для викладання курсів $з$ паліативної та хоспісної допомоги для студентів медичних спеціальностей;

\section{Література}

1. Новиков Г. А. Паллиативная помощь онкологическим больным / Г. А. Новиков, В. И. Чиссов (ред.). - М. : ООД : Медицина за качество жизни, 2006. - 192 с.

2. Загальний огляд медико-демографічної ситуації та аналіз тенденцій у сфері охорони здоров'я за останні п'ять років (2002-2006 pp.) / [Д. Д. Айстраханов, М. В. Банчук, I. I. Волинкін та ін.] // Україна. Здоров’я нації : науково-практичне видання. -К. : Видавництво “Експерт”, 2007. -С. 7-16.

3. Безруков В. В. Проблеми здоров'я літніх людей та забезпечення їм медичної допомоги в Україні / В. В. Безруков, Н. В. Вержиковська, В. В. Чайковська // Журнал АМН України.-2000.-№ 1.-С. 93-106.

4. Москвяк Є. Й. Організаційні проблеми надання допомоги інкурабельним хворим / С. Й. Москвяк // Врачебное дело. -2007.- № 4. - С. 86.

5. Дячук Д. Організаційні підходи до надання паліативної медичної допомоги інкурабельним онкологічним хворим / Д. Дячук // Вісник соціальної гігієни та організації охорони здоров’я України. - 2003. - № 2. - С. 48-54.

6. Лапотников В. Паллиативная помощь / В. Лапотников // Новые Санкт-Петербургские врачебные ведомости. -2003. - № 1.-С. 34-38.

7. Губський Ю. І. Розвиток паліативної допомоги в Україні : перешкоди та перспективи / Ю. І. Губський // Доповідь Президента Всеукраїнської ради захисту прав та безпеки пацієнтів на засіданні Президії Міжнародного благодійного фонду “Відродження”. -20.10.2003 р.

8. Лечение болевого синдрома в онкологии / [О. Е. Боб-
- створити умови для набуття і удосконалення навичок надання паліативної та хоспісної допомоги, в першу чергу, стосовно контролю больового синдрому та інших проявів захворювань, що потребують паліативної та хоспісної допомоги, а також щодо спілкування та консультування паліативних хворих $\mathrm{i}$ членів їхніх родин.

ров, Л. Н. Брындиков, А. В. Кравченко и др.]. - Ровно, 2003. $-196 \mathrm{c}$.

9. Opieka paliatywna na Ukrainie: osiagniecia i perspektywy. Yu. Gubsky, W. Serdiuk, S. Martyniuk-Gres, A. Tsarenko, A. Wolf// Clinical and Experimental Letters. -2007.- Vol. 48, Suppl. B. P. 23-24.

10. Паліативна медицина : організаційні і педагогічні аспекти / Г. Боднар, I. Вітенко, А. Попович [та ін.] // Медична освіта. -2003. - № 2. - С. 7-9.

11. Стан паліативної допомоги в Україні та медсестринська освіта / Р. І. Сидорчук, О. Й. Хомко, О. А. Рудек [та ін.] // Медична освіта. - 2008. - № 2.-С. 102-104.

12. Improving of palliative care specialists' training in Ukraine / A. Tsarenko, V. Serdiuk, S. Martyniuk-Gres, L. Shkoba // Palliative Care in Different Cultures. The 2nd International Conference in Palliative Care. Eilat, Israel, 2008, p. 80.

13. Advancing Palliative Care: The Public Health Perspective. Foreword / M. Callaway, F. D. Ferris // J. Pain Symptom Management.-2007. - Vol. 33,(5).-P. 483-485.

14. Stjernsward J. The Public Health Strategy for Palliative Care/ J. Stjernsward, K. M. Foley, F. D. Ferris // J. Pain Symptom Management. -2007.-Vol.33,(5).-P. 486-493.

15. Brennan F. Palliative Care as an International Human Right / F. Brennan // J. Pain Symptom Management. - 2007. Vol. 33,(5).-P. 494 499.

16. Бондар Г. В. Паліативна медична допомога : посібник / Г. В. Бондар, І. С. Вітенко, О. Ю. Попович. - Донецьк : Донеччина, 2004. - 80 с. 